\title{
The Effect of Modes of Development on Intermediate Learners' Written Language Production
}

\author{
Asghar Salimi(Corresponding Author), Marjan Sattaran,Davoud Amini \\ Department of English ,University of Maragheh, Maragheh, Iran \\ Department of Teaching English as a second language, Sarab Branch, \\ Islamic Azad University, Sarab, Iran \\ Department of English, Azarbaijan Shahid Madani University,Iran
}

ABSTRACT

\begin{abstract}
It is believed that task-based instruction language teaching prepared a convenient condition and chance for $L 2$ acquisition. This is the reason why tasked-based instruction teaching has been highlighted by many L2 languages in instructors and even syllabus designer. However there would be some differences in L2 learner's written performance in different kinds of genre with regard to the effect of tasked based instruction. This paper intended to find and examine the effect of genretic features of four types of genre as descriptive, narrative, argumentative and expository in order to measure fluency, accuracy and complexity. To reach the aim of the study, 120 essay samples of 30 intermediate students were analyzed. The most important goal of this study is to analyze task complexity for selecting, sequencing and even grading material in syllabus designing for task and syllabus designer.
\end{abstract}

\section{Indexing terms/Keywords}

Task-based language teaching, Genre, Accuracy, Fluency, Complexity.

\section{Academic Discipline And Sub-Disciplines}

Language Teaching and Learning; language studing, writing and Genre analysis

\section{SUBJECT CLASSIFICATION}

ELT language classification

\section{TYPE (METHOD/APPROACH)}

Descriptive Analysis

\section{Council for Innovative Research}

Peer Review Research Publishing System

Journal: Journal of Advances in Linguistics

Vol 6, No 2.

editor@cirjal.com

www.cirjal.com, www.cirworld.com 


\section{INTRODUCTION:}

Second language learners are always under investigation and analysis of researcher, teacher and even linguists when they are speaking, writing and in whole words "communicate". In the process of production an utterance especially in written form, many factor as topic familiarity, types of task, structure of task, genre of task and even the time which was allocated by student to the task should be consider.(Sattaran,2013)

Written language's use characterized as a kind of non-reciprocal interaction \& shows the roles of writer in discourse participant. In fact written language is the manifestation of syntactic and semantic rules. According to widdoson written discourse occurs as a realization of linguistic rules in the act of making sense and this inevitably involve an engagement with language user's cognitive and experimental reality( Widdoson,1984:44)Today, discourse has been found out analyzed and compared in various ways and more recently as "genre". Genre analysis as a power full and comprehensible system is a well-constructed approach for analyzing the form and rhetorical function.. According to Hyland (2005):

Genre is a term for grouping text together, representing how writers use language

to response to recurring situation.

Task-based language teaching (TBLT) is an approach to create more favorable condition for the development of second language (Rahimpout,2007). That's why today it has attracted many SLA researcher and syllabus designer (Ellis 2003, 2005; Tavakoli and Foster, 2008). This approach to L2 teaching tries to highlight learner's ability in performing target like task when there is no sign of grammatical rule. We can conclude in this way that there is no teaching of grammar in TBLT.

\section{LITRETURE REVIEW}

\section{Genre analysis (Concept of Genre)}

By 1980s, many researcher and studies could not provide a complete comprehensible model for academic text and scientific work. With the increase of demand for analyzing the written and spoken language and with development of academic reading and writing in which structural features were important, "Genre" analysis became a means of studding spoken and written discourse for applied ends. Having knowledge of genre can play an important role in the setting of the text which is used in professional and institutional context.(Bahatia,2005). Hyland argues that genre is a term for grouping text together, representing how writers use language to respond to recurring situation.(2005. P,58). In a simple word, genre is use to classify text into kinds and consisted of communicative events which happen through the member of that community. There have been many changes toward the concept of genre; spoken or written, remains a fussy concept as it becomes associated with disreputably formulaic way of constructing particular text whether written or spoken.(Sattaran,2013)

\section{Definition of Genre}

Genre analysis as a powerful and comprehensive system is well-constructed approach that creates a more highlighted power to language. Swailian definition of genre analysis includes:

It comprises and analyzes a class of communicative events, the member of which share some set of the parent discourse community and influence and constrain choice of content style. Communicative purpose is both privilege criterion and one that to keep the scope of genre as convinced narrowly focused on comparable rhetorical action. The genre names inherited and produce by discourse communities and imported by other constitute valuable ethnographic, but typically need further validation (Swale, 1990; 58).

According to Kramsh(1998) genre is socially sanctioned type of communication event, either spoken or printed perceived as such within a specific concept of situation or culture. The concept of genre is related to text type and language choice.

\section{Tasked based}

Task-based language teaching (hereinafter TBLT) is an approach to syllabus design which focuses on learner's performance while there is no explicit grammatical structure to teach. This approach is highlighted in second language learning as its focuses is on identifying learner's need as well as student's achievement measurement . This approach has been investigated by many scholars like Ellis (2003, 2009), Skehan and Foster(1999), Robinson(2001,2007), Tavakoli \& Skehan (2005), Rahimpour(2010) and Salimi(2009).

Ellis (2009) defined task based language teaching in this way that TBLT is an approach for second or foreign language that engage learner in interactionally authentic language use by getting learner to perform a series of task, enable learner to acquire new language system as well as procederalize existing knowledge.

Not only teachers attention to TBLT, but also syllabus designer and researcher is worth to consider. Prabhu(1987) pointed out TBLT has no important role and effectiveness in language development.

\section{Task complexity}

Complexity of second language task is one of the important pedagogical implication and decision for syllabus designer in process of designing a course. In sequencing and grading of a task "syllabus complexity" of a task should be consider.( Rahimpour,1997;Robinson, 2003.2005; Salimi and Yousefi,2009). Robinson defined task complexity as bellow: 
task complexity is the result of attentional, memory, reasoning and other information processing demands imposed by the structure of task to the language learner.(2001,P:29)

Task complexity refer to cognitive property and complexity within a task in which learner perform differently which pointed out by Ellis (2003) and Robinson as "learner variability" with

task complexity.

\section{RESEARCH QUESTION}

This study is aimed to investigate the following research question and hypothetic:

$\mathbf{R Q}$ : what is the effect of modes of development (generic feature of task) on learner's written performance?

RH (Null Hypothesis): There is no significant effect of mode of development (generic feature) on learner's written performance.

\section{METHOD}

Participant: those who considered as a participant in this study were 30 English language learners (intermediate level). They were both female and male in genders who were studying in one institute in west Azarbaijan, Iran.

Material and Procedure: In order to collect data, student were asked to write down and perform 4 kinds of task as follow: first, they asked to write and expository writing (effect of watching TV on children), descriptive writing (describing special time) was considered as their second task. Then they were required to perform and an argumentative task (is money an effective motivator at job?) and at last they were required to narrate down a process( how did you learned to use computer?)

\section{RESULT}

In this study 3 elements of written performance as fluency, accuracy and complexity have been analyzed in order to measure students' performance in term of fluency, accuracy and complexity in each task. Measurement software SPSS have been used to analyzed students performance in terms of fluency, accuracy and complexity. ANNOVA used as a means of comparison among learners' performance.

Table bellow shows the differences between learner's performance in terms of accuracy, fluency and complexity in descriptive task. As it is presented here learners' performance in fluency is greater than learners' performance in accuracy and complexity. We can conclude in this way that mode of development in descriptive task has less effect on accuracy and most effect on fluency.

Table1. Learners performance in Descriptive task (Describe your holiday) in terms of accuracy,

\begin{tabular}{|c|c|c|c|}
\hline \multicolumn{5}{|c|}{ fluency and complexity } \\
\cline { 2 - 4 } & PERFORMANCE & $\begin{array}{c}\text { NUMBER OF } \\
\text { STUDENTS }\end{array}$ & MEAN \\
\cline { 2 - 4 } & Accuracy & 30 & 0.3181 \\
\cline { 2 - 4 } & Fluency & 30 & 91.8532 \\
\cline { 2 - 4 } & Complexity & 30 & 45.6152 \\
\cline { 2 - 4 } & Total & 90 & 45.9288 \\
\hline
\end{tabular}


Fig1. Learners performance in Descriptive task (Describe your holiday) in terms of accuracy, fluency and complexity

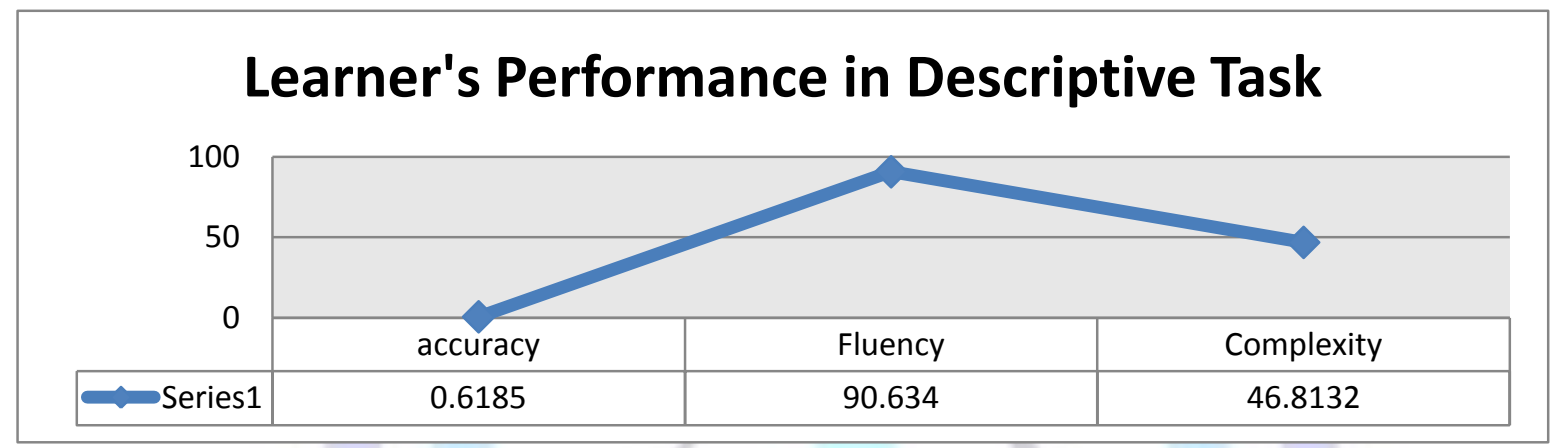

As table 2. Presented here we can see that learners' performance in terms of accuracy, fluency and complexity in narrative task. Modes of development in narrative task has less influence on accuracy and most effect on fluency.

Table2. Learners performance in Narrative task (How did you learn to use your computer?) in terms of accuracy, fluency and complexity

\begin{tabular}{|c|c|c|c|}
\hline \multirow{5}{*}{ 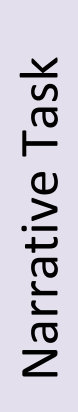 } & erforman & $\begin{array}{c}\text { Number Of } \\
\text { Students }\end{array}$ & Mean \\
\hline & Accuracy & 30 & 0.6185 \\
\hline & Fluency & 30 & 90.634 \\
\hline & Complexity & 30 & 46.8132 \\
\hline & Total & 90 & 46.0219 \\
\hline
\end{tabular}

Fig2. Learners performance in descriptive task (How did you learn to use your computer?) in terms of accuracy, fluency and complexity.

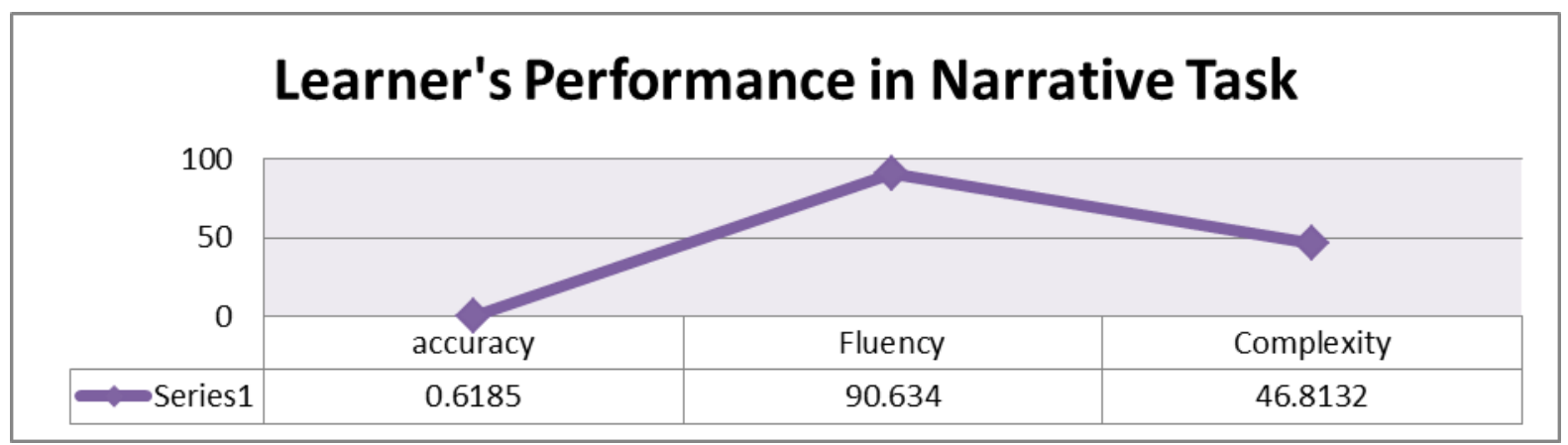

Table 3. Refer to learners' performance in term of accuracy, fluency and complexity in expository task. Fluency in modes of development in this task is greater than accuracy and complexity as represented bellow: 
Table3. Learners performance in Expository task (Effect of watching TV on children) in terms of accuracy, fluency and complexity

\begin{tabular}{|c|c|c|c|}
\hline \multirow{5}{*}{ 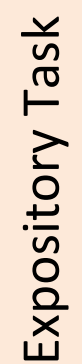 } & Performance & Number of Students & mean \\
\hline & accuracy & 30 & 0.134 \\
\hline & Fluency & 30 & 64.735 \\
\hline & Complexity & 30 & 29.6198 \\
\hline & Total & 90 & 31.4968 \\
\hline
\end{tabular}

Fig3. Learners performance in descriptive task (Effect of watching TV on children) in terms of accuracy, fluency and complexity

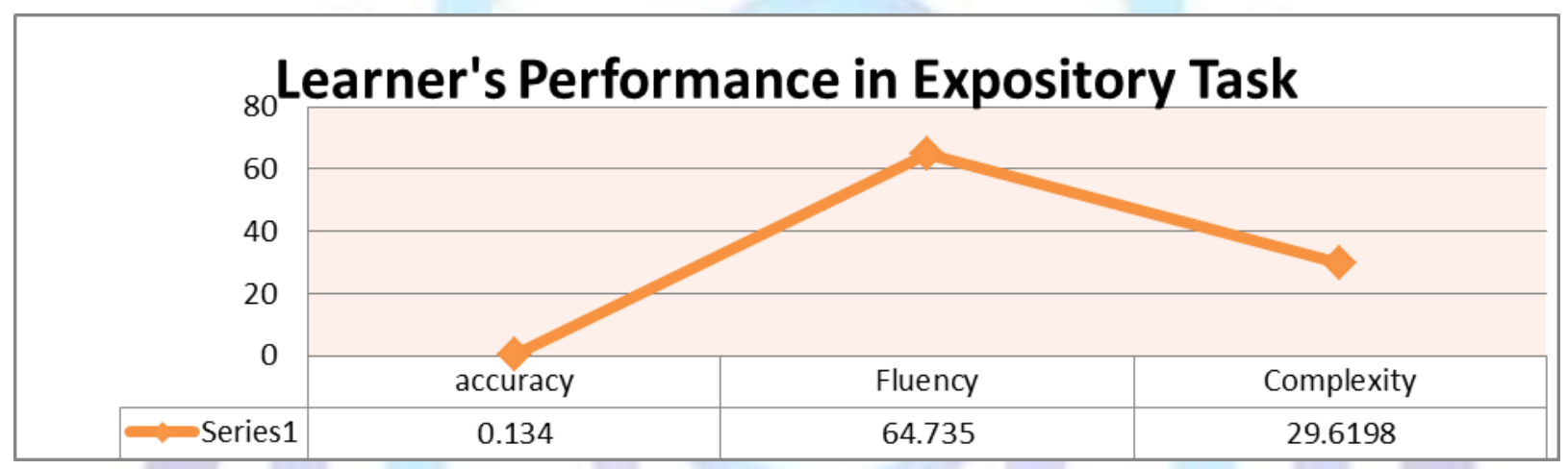

Table 4. Shows the differences between learner's performance in terms of accuracy, fluency and complexity in Narrative task.. As it is represented here we can conclude that mode of development in Narrative task has less effect on accuracy and most effect on fluency.

Table4. Learners performance in descriptive task (Is money effective motivator at work?) in terms of accuracy, fluency and complexity

\begin{tabular}{|c|c|c|c|}
\hline \multirow{5}{*}{ 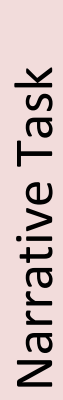 } & Performance & Number of Students & mean \\
\hline & accuracy & 30 & 0.3081 \\
\hline & Fluency & 30 & 78.6173 \\
\hline & Complexity & 30 & 39.6848 \\
\hline & Total & 90 & 39.5367 \\
\hline
\end{tabular}


Fig4. Learners performance in descriptive task (Is money effective motivator at work?) in terms of accuracy, fluency and complexity

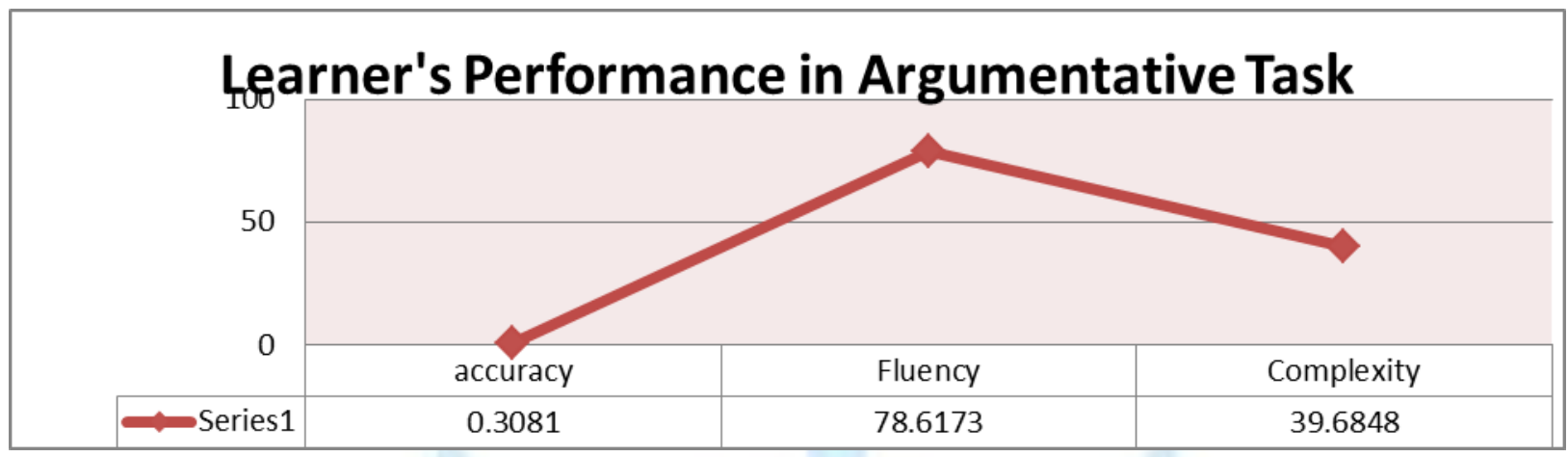

\section{DISCUSSION}

According to Robinson's cognitive hypothesis (2005), increasing cognitive load of task will increase accuracy, complexity but not fluency. He believes in the more cognitive load of task, the greater accuracy learner will have to perform in their task. Here regarding the effect of modes of development of task in second language learners' production in form of written task and their fluency we can conclude that there is no brilliant differences in learners' modes of development and against Robinson's cognitive hypothesis, not only fluency increased but also it was the most greater among two other performance elements and it is in consistence with Skehan and Foster (1999) which conclude that the structure of task will increase the fluency of language production.

Considering modes of development of L2 learners' written production in terms of complexity, we can come to this conclusion that finding of this study is in accordance with Robinson's model (2005) that increasing load of task will ends to increasing complexity. Skenhan's model in which predisposition is on learners to orient performance in one or two aspect of modes of development is worth to note. However, result of this study is against the findings of studies done by researchers like Tavakoli \& Skehan (2005).

As finding of this study represents, in relation to the effects of modes of development of task on L2 learners' written production in terms of accuracy and with regard to the results of the present study we can conclude that modes of development and features of task had no brilliant effect on accuracy of L2 learners' written production . The result and analysis of this study in modes of development and in terms of accuracy is in line with the findings of the study which proposed by Skehan \& Foster (1999). Moreover, the finding of this study is in contrast with the findings of the studies like and Tavakoli \& Skehan (2005). Modes of development in terms of accuracy, is less effects than two other areas of performance. Skehan and Foster (1999) believed that one way of influencing accuracy is using pre-task to have a chance of improving structure of task in their performance. It means that students who did not have a pre-task activity won't be able to perform well in their accuracy and the structure of the task will not be familiar for them so the rate of accuracy will decrease.

\section{PEDAGOGICAL IMPLICATION}

The present study's pedagogical implication can be considered for second language teachers and syllabus designer. According to Brown(1991) Task requiring learners to interpret information, lead to greater complexity in language and performance of L2 learner in term of modes of development like complexity, accuracy and fluency is so important to consider as they lead to task design. According to Robinson (2001; P:288-292) syllabus design is based on a decision about the unit of classroom activity and sequence in which they are to be performed and achieved. In tasked based instruction, achievement means whether and to what extent learner can successfully performed. Therefore, determining a valid criteria for sequencing a task should be considered. However it is important for syllabus designer and teacher to design a task and activity which is requires higher rate of modes of development and performance as accuracy, fluency and complexity. Findings of this study can be a measure for selecting, grading and even sequencing a task in order to reach a higher rate of performance and modes of development.

\section{REFERENCE}

[1] Bahatia, V.K (2005). World of Written Communication. New York: Continuum.

[2] Brown,R. (1991). Group Work, Task Differences and Second Language Acquisition. Applied Linguistic, 11,11-12

[3] Candlin, C. (1987). Toward Task- based Language leraning. In C.Candline, \& D. Murphy Language Leraning Task. (pp.5-22). London: Prentice Hall

[4] Ellis, R. (2003). Task-Based Language Learning And Teaching. Oxford: Oxford University Press 
[5] Ellis, R. (2005). Planning and Task Performance in a Second Language. Amesterdam: John Benjamin

[6] Ellis, R. (2009). Task-Based Language Teaching: Sorting Out The Misunderstandings. International Journal of Applied Linguistics Vol. 19, 3. Pp:229-246.

[6] Hyland, K. (2005). Metadiscourse: Exploring Interaction in writing. Continuum: Oxford University Press

[7] Kramsh,C. (1998). Language and Culture. Oxford University press

[8] Nunan,D. (1989). Designing Task for Communicative Classroom. Combridge: Cambridge University Press

[9] Prabhu, N. (1987). Second language pedagogy. Oxford: Oxford University Press.

[10] Rahimpour, M. (1997). Task complexity, task condition, and variation in L2 oral discourse. Unpublished Ph.D. thesis, University of Queensland, Australia.

[11] Rahimpour, M. (1999). Task complexity and variation in interlanguage. In N. O. Jungheim\& P. Robinson (Eds.), Pragmatic and pedagogy: proceeding of the3rd pacific Second Language Research Forum, (pp.115-134).Tokyo, Japan: Pac LRF.

[12] Rahimpour, M.(2007). Task Complexity and Variation in L2 learners' Oral Discourse. Working papers in Language and Linguistics, University of Queenland, 1-9

[13] Rahimpour, M. (2008). Implementation of task-based approaches to language teaching. Pazhuhesh-e- Zabanha-ye Khareji Journal, University of Tehran, 41,45-61.

[14] Rahimpour, M.(2010). Current Trends on Syllabus Design in FL Instruction. Procedia Social and Behavioral Science. Vol. 2. PP:1660-64

[15] Robinson, P. (2001). Task complexity, task difficulty, and task production: exploring interactions in a componential framework. AppliedLinguistics, 22(1), 27-57.

[16] Robinson, P. (2003). The cognition hypothesis, task design, and adult task-based language learning. Second Language Studies, 21(2), 45-105.

[17] Robinson, P. (2005). Cognitive complexity and task sequencing: studies in a componential framework for second language task design. International Review of Applied Linguistics, 43, 1-32.

[18] Robinson, P. (2007). Triadic framework for TBLT: Task complexity, task difficulty, and task condition. The Journal of Asia TEFL. pp: 195-225

[19] Sattaran, M. (2013). A Move-based Analysis of Interactional Metadicourse in Applied Linguistics Text books; Native Vs. Non-native Writers.(2013). Published MA Thesis, University of Maraghe,Iran.

[20] Salimi,A.\& Yusefi,M. (2009). The Effect of Task Complexity on L2 Leraners' Uptake in EFL Context. A Paper Presented at 7th International TELLSI Conference. University of Yazd, October 2013.

[21] Salimi, A. \& Dadashpour, S. (2010). Task complexity and L2 learners' written performance. A paper presented at WCCES 14. Bogazici University, Istanbul, Turkey, 14-18 June.

[22] Salimi,A.,Shafaei, A.,\& Kuhi, D.(2012). The Effect of Generic Features of Task on L2 Learners' Oral Performance. Theory and Practice in Language Studies, Vol. 2, No. 4, PP. 820- 825,April 2012.

[23] Skehan, P. (1998a). Task-based instruction. Annual Review of Applied Linguistics, 18, 268-286.

[24] Skehan, P. \& Foster, P. (1999). The influence of task structure and processing conditions on narrative retellings. Language Learning, 49(1), 93-120.

[25] Swales, J.( 1990). Genre Analysis: English in Academic \& research setting. New York: Cambridge University Press

[26] Tavakoli , P. \& Foster, P.. (2008). Task Designe and Second Language Performance: The effects of Narrative Type on Learners' Output. Language Learning. 58:2, 439-473.

[27] Tavakoli, P. \& Skehan, P. (2005). Strategic planning, task structure and performance testing. In R. Ellis (Ed.), Planning and task performance in a second language (pp. 239 - 277). Amsterdam: Benjamins.

[28] Widdowson, H.G.(1984). Exploration in Applied Linguistic 2. Oxford university Press 


\section{AUTHOR BIOGRAPHY}

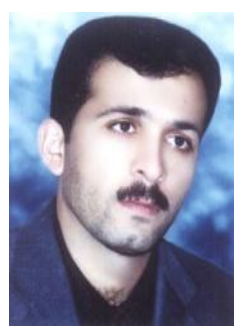

Asghar Salimi is a PhD in applied linguistics .He is an assistant Proffessor in applied linguistic, Department of English University of Maragheh, Maragheh, Iran . He has been teaching English for over 10 years at several universities for B.A and M.A students in TEFL. He has presented more than ten papers in different national and international conferences in different countries. His main areas of interest are task-based learning and teaching, syllabus design, and Second Language Acquisition (SLA).

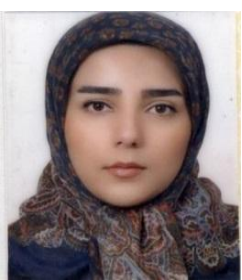

Marjan Sattaran is a Phd student in TEFL in Azad university of Sarab. She has experience of teaching in Payam Nour University as well as Iran National Language Complex. She holds an M.A from Islamic Azad University, Maragheh Branch. Her main areas of interest are task-based language teaching and genre analysis.

Davoud Amini is a PhD in applied linguistics. He is an assistant Proffessor in applied linguistic, Department of English Azarbaijan Shaid Madani University, Iran. He is teaching Englush more than 10 years in different universities of Azarbaijan.

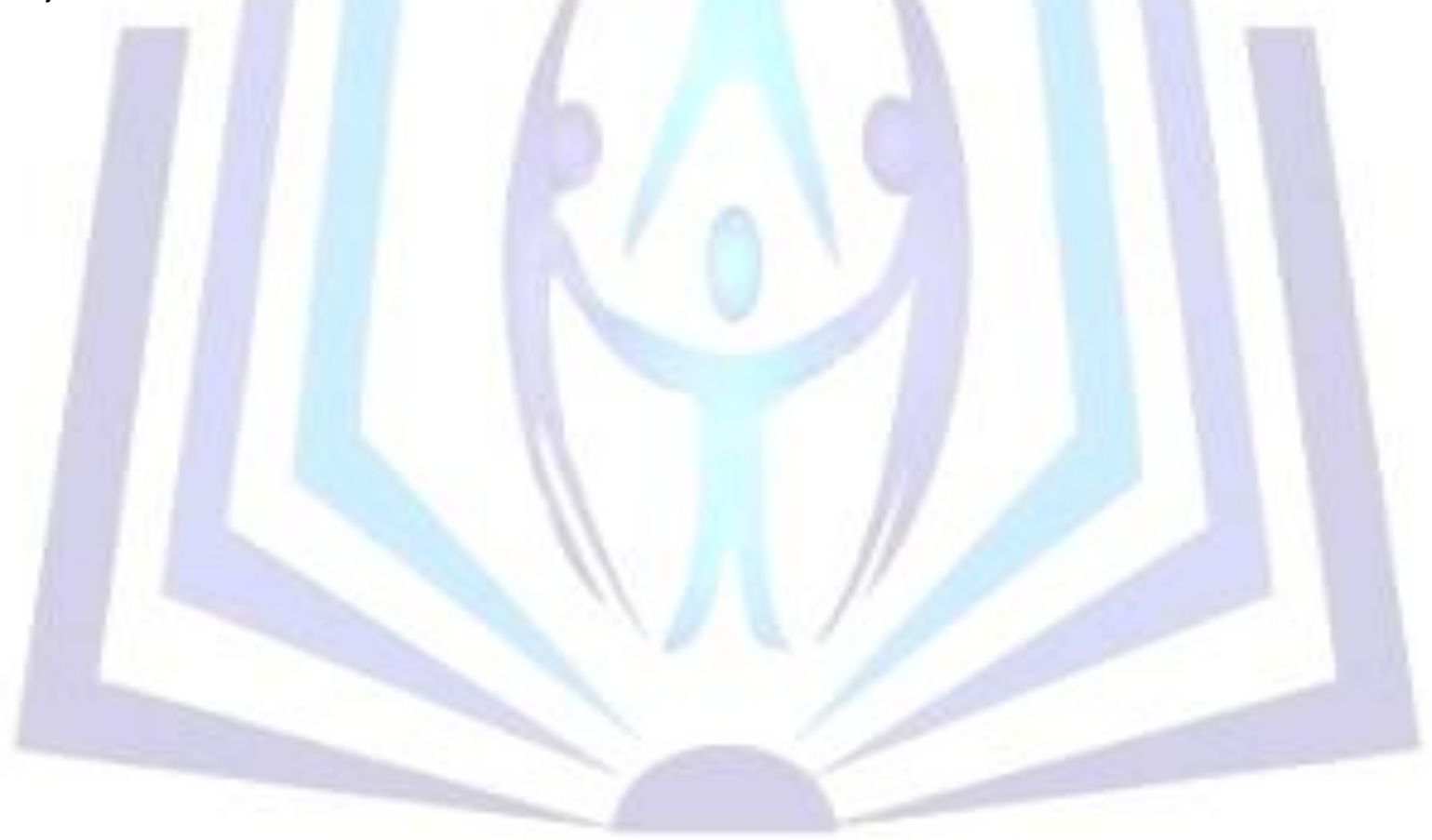

